\title{
Effect of New Molecules of Insecticides on Shoot Fly (Atherigona soccata) (Rondani) Incidence and Grain Yield of Sorghum
}

\author{
S.P. Patil* and A.S. Bagde \\ Department of Agri. Entomology, College of Agriculture, \\ Kolhapur - 416 004, Maharashtra, India \\ *Corresponding author
}

A B S T R A C T

\begin{tabular}{l} 
K e y w or d s \\
$\begin{array}{l}\text { Sorghum, } \\
\text { Atherigona soccata. }\end{array}$ \\
\hline Article Info \\
\hline $\begin{array}{l}\text { Accepted: } \\
\text { 26 August } 2017 \\
\text { Available Online: } \\
\text { 10 September } 2017\end{array}$ \\
\hline
\end{tabular}

Bioefficacy of different insecticides against sorghum shoot fly Atherigona soccata (Rondani) was studied. The experiment was laid out in randomized block design with seven treatment and four replications with view to find out the effective insecticides against sorghum shoot fly at Agronomy field, college of agriculture Kolhapur during Rabi 2016-17. Cultivar Phule Vasudha was sown on $24^{\text {th }}$ October. The insecticide used for the treatment were Chlorantraniliprole 18.5 SC, Flubendiamide 20 WG, Deltamethrin 2.8 EC, Quinalphos 25 EC, Azadirachtin 10,000 PPM and Buprofezin 25 SC. The results of present investigation revealed that the treatment with Deltamethrin 2.8 EC @ 1ml/1 at 28 DAE was significantly most effective treatment for the control of sorghum shoot fly.

\section{Introduction}

Sorghum [Sorghum bicolor (L.) Monech] is the fifth most important cereal crop worldwide after wheat, rice, maize and barley (FAO, 2011). In Maharashtra, sorghum is being grown on 5.50 million hectares and production is 6.05 million tonnes. Sorghum shoot fly, Atherigona soccata Rondani (Order- Diptera, Family- Muscidae) is the most destructive one and causes severe damage in the early i.e. seedling stage and last up to 4 weeks causing severe reduction in plant population thereby causing heavy yield losses. The maggot crawls to the plant whorl and then moves downward between the fold of young leaves till they reach the growing point. It cuts the growing tip and feeds on the decaying leaf tissues, which results in dead heart formation. Researchers have worked on the management of shoot fly with insecticidal and non-insecticidal approach which has indicated that chemical control measures become inevitable approach in a certain stage in the management of this pest (Shivpuje and Thombre 1983; Patil et al., 1992; Panchabhavi and Kotikal, 1992). Under such situation it becomes inevitable to protect the crop under plant protection umbrella at least with minimum use of synthetic insecticides. It was therefore planned to test newly launched synthetic insecticides viz., chlorantraniliprole 18.5 SC and flubendiamide $20 \mathrm{WG}$ with different doses against sorghum shoot fly. 


\section{Materials and Methods}

The experiment was laid in simple randomized block design with seven treatments and four replications. Net plot size was $2.40 \times 3.10 \mathrm{~m}^{2}$ with four rows. Row to row and plant to plant spacing was $45 \mathrm{~cm}$ and $15 \mathrm{~cm}$, respectively. In order to avoid the pesticides drift, distance of one and half meter between two replications was maintained. The observations on the number of eggs laid by shoot fly on the lower surface of leaves on the randomly selected five plants were recorded on $10^{\text {th }}$ and $20_{\text {th }}$ day after emergence of plants. The level of shoot fly incidence was determined on the basis of per cent dead hearts in each plot. For this purpose observations were recorded on $14^{\text {th }}, 21^{\text {st }}$ and $28^{\text {th }}$ day after emergence. Total number of plants and plant showing dead hearts were counted from each plot and percentages of dead hearts in treatment were worked out. Ear heads were harvested after the crop maturity and threshed separately replication wise for each treatment and to record grain weight $(\mathrm{kg} / \mathrm{plot})$. Mean yield of respective treatments were converted to quintal per hectare

\section{Results and Discussions}

The data on the number of eggs laid by sorghum shoot fly at $10^{\text {th }}$ and $20^{\text {th }}$ day after emergence are presented in table 1 . The significantly highest number of eggs $(0.26$ eggs per plant) were recorded on $10 \mathrm{DAE}$ in the plot treated with deltamethrin 2.8 EC @ $1 \mathrm{ml} / \mathrm{l}$ and was at par with plot treated with chlorantraniliprole 18.5 SC @ 0.3 gm/l (0.25eggs per plant).

The next higher number of eggs was recorded in the plot treated with flubendiamide $20 \mathrm{WG}$ @ $0.2 \mathrm{gm} / \mathrm{l}(0.24)$ and was at par with quinalphos $25 \mathrm{EC} @ 2 \mathrm{ml} / 1$ (0.23). The rest of treatments recorded less number of eggs of shoot fly and were at par with each other. The treatments in their descending order were azadirachtin 10,000 PPM @ 3ml/1 (0.20), untreated control (0.19) and buprofezin $25 \mathrm{EC}$ @ $1.25 \mathrm{ml} / \mathrm{l}(0.18)$. The significantly lowest number of eggs (0.19 eggs per plant) were recorded in the plot treated with deltamethrin 2.8 EC@1ml/l and was at par with plot treated with chlorantraniliprole 18.5 SC @ 0.3 $\mathrm{gm} / \mathrm{l}$ (0.20 eggs per plant).The next lower number of eggs were recorded on $20 \mathrm{DAE}$ in the plot treated with flubendiamide 20 WG @ $0.2 \mathrm{gm} / 1$ (0.22) and was at par with quinalphos $25 \mathrm{EC} @ 2 \mathrm{ml} / \mathrm{l}(0.22)$.The rest of treatments recorded less number of eggs of shoot fly and were at par with each other. The treatments in their descending order were azadirachtin 10,000 PPM @ 3ml/1 (0.25), buprofezin 25 EC @ $1.25 \mathrm{ml} / \mathrm{l}(0.26)$ and untreated control (0.27).In present investigation deltamethrin 2.8 EC @ $1 \mathrm{ml} / 1$ found to be significantly superior as compared to all insecticides. Similar result was observed by Pawar et al., (2015) for rabi sorghum.

\section{Following treatments were included in the experiment}

\begin{tabular}{|c|c|c|c|}
\hline Tr. No. & Treatment & Dose & Form and time of application \\
\hline $\mathrm{T}_{1}$ & Chlorantraniliprole $18.5 \mathrm{SC}$ & $0.3 \mathrm{ml} / 1$ & Foliar spray at 10 and $20 \mathrm{DAE}$ \\
\hline $\mathrm{T}_{2}$ & Flubendiamide $20 \mathrm{WG}$ & $0.2 \mathrm{~g} / 1$ & Foliar spray at 10 and $20 \mathrm{DAE}$ \\
\hline $\mathrm{T}_{3}$ & Deltamethrin $2.8 \mathrm{EC}$ & $1 \mathrm{ml} / 1$ & Foliar spray at 10 and $20 \mathrm{DAE}$ \\
\hline $\mathrm{T}_{4}$ & Quinalphos $25 \mathrm{EC}$ & $2 \mathrm{ml} / 1$ & Foliar spray at 10 and $20 \mathrm{DAE}$ \\
\hline $\mathrm{T}_{5}$ & Azadirachtin $10,000 \mathrm{PPM}$ & $3 \mathrm{ml} / 1$ & Foliar spray at 10 and $20 \mathrm{DAE}$ \\
\hline $\mathrm{T}_{6}$ & Buprofezin $25 \mathrm{EC}$ & $1.25 \mathrm{ml} / 1$ & Foliar spray at 10 and $20 \mathrm{DAE}$ \\
\hline $\mathrm{T}_{7}$ & Untreated control & - & - \\
\hline
\end{tabular}


Table.1 Effect of different insecticidal treatments on oviposition of sorghum shoot fly

\begin{tabular}{|c|c|c|c|}
\hline \multirow{2}{*}{$\begin{array}{c}\text { Tr. } \\
\text { No. }\end{array}$} & \multirow{2}{*}{ Treatment } & \multicolumn{2}{|c|}{ Average number of eggs per plant on } \\
\cline { 2 - 4 } & $\mathbf{1 0}^{\text {th }} \mathbf{D A E}$ & $\mathbf{2 0}^{\text {th }}$ DAE \\
\hline $\mathrm{T}_{1}$ & Chlorantraniliprole 18.5 SC & $0.25(0.87)^{*}$ & $0.20(0.83)$ \\
\hline $\mathrm{T}_{2}$ & Flubendiamide 20 WG & $0.24(0.86)$ & $0.22(0.85)$ \\
\hline $\mathrm{T}_{3}$ & Deltamethrin 2.8 EC & $0.26(0.87)$ & $0.19(0.83)$ \\
\hline $\mathrm{T}_{4}$ & Quinalphos 25 EC & $0.23(0.85)$ & $0.22(0.85)$ \\
\hline $\mathrm{T}_{5}$ & Azadirachtin 10,000 PPM & $0.20(0.83)$ & $0.25(0.87)$ \\
\hline $\mathrm{T}_{6}$ & Buprofezin 25 SC & $0.18(0.82)$ & $0.26(0.87)$ \\
\hline $\mathrm{T}_{7}$ & Untreated Control & $0.19(0.83)$ & $0.27(0.88)$ \\
\hline & S.E. & 0.0036 & 0.0048 \\
\hline & C.D. at 5\% & 0.0106 & 0.0142 \\
\hline
\end{tabular}

*Figures in parentheses are square root transformed values

DAE: Day after emergence

Table.2 Effect of different insecticidal treatments on dead hearts caused by sorghum shoot fly

\begin{tabular}{|c|c|c|c|c|}
\hline \multirow{2}{*}{$\begin{array}{c}\text { Tr. } \\
\text { No. }\end{array}$} & \multirow{2}{*}{ Treatment } & \multicolumn{3}{|c|}{ Average per cent dead hearts } \\
\cline { 2 - 5 } & & $\mathbf{1 4}^{\text {th }} \mathbf{D A E}$ & $\mathbf{2 1}^{\text {st }} \mathbf{D A E}$ & $\mathbf{2 8}^{\text {th }}$ DAE \\
\hline $\mathrm{T}_{1}$ & Chlorantraniliprole 18.5 SC & $4.54(12.3)^{*}$ & $8.31(16.75)$ & $11.47(19.80)$ \\
\hline $\mathrm{T}_{2}$ & Flubendiamide 20 WG & $5.66(13.76)$ & $10.35(18.77)$ & $13.41(21.48)$ \\
\hline $\mathrm{T}_{3}$ & Deltamethrin 2.8 EC & $4.32(12.00)$ & $7.97(16.40)$ & $10.84(19.22)$ \\
\hline $\mathrm{T}_{4}$ & Quinalphos 25 EC & $6.01(14.19)$ & $10.71(19.10)$ & $14.10(22.06)$ \\
\hline $\mathrm{T}_{5}$ & Azadirachtin 10,000 PPM & $7.00(15.34)$ & $11.70(20.00)$ & $15.46(23.15)$ \\
\hline $\mathrm{T}_{6}$ & Buprofezin 25 SC & $7.94(16.37)$ & $12.27(20.50)$ & $15.89(23.49)$ \\
\hline $\mathrm{T}_{7}$ & Untreated Control & $8.14(16.58)$ & $14.72(22.56)$ & $17.01(24.36)$ \\
\hline & S.E. \pm & 0.34 & 0.38 & 0.41 \\
\hline & C.D. at 5\% & 1.02 & 1.14 & 1.23 \\
\hline
\end{tabular}

*Figures in parentheses are arcs in transformed values DAE: Day after emergence

Significantly less per cent of dead hearts $(4.32 \%)$ were recorded on $14 \mathrm{DAE}$ in the plots treated with deltamethrin 2.8 EC @ $1 \mathrm{ml} / \mathrm{l}$ was at par with chlorantraniliprole 18.5 SC@0.3gm/l (4.54\%) (Table 2). These treatments were found to be superior in reducing shoot fly damage over rest of the treatment. The next best treatment was flubendiamide 20 WG @ 0.2gm/l (5.66\%) and quinalphos 25 EC @ 2ml/1 (6.01\%) and was at par with each other. However, these were followed by azadirachtin 10,000 PPM @ $3 \mathrm{ml} / 1$ (7.00\%), buprofezin $25 \mathrm{SC} @ 1.25 \mathrm{ml} / 1$ (7.94\%). All these treatments were significantly superior over untreated control. Maximum dead hearts were recorded in untreated control $(8.14 \%)$. All the insecticidal treatments recorded significantly less per cent of dead hearts over untreated control. Significantly less per cent of dead hearts (7.97\%) were recorded on 21DAE in the plots treated with deltamethrin $2.8 \mathrm{EC} @ 1 \mathrm{ml} / 1$ was at par with chlorantraniliprole 18.5 SC @ $0.3 \mathrm{gm} / \mathrm{l}(8.31 \%)$. These treatments were found to be superior in reducing shoot fly damage over rest of the treatment. The next best treatment was flubendiamide 20 WG @ $0.2 \mathrm{gm} / 1(10.35 \%)$ and quinalphos 25 EC @ $2 \mathrm{ml} / 1(10.71 \%)$ and was at par with each other. Significantly less per cent of dead hearts $(10.84 \%)$ were recorded on 28 DAE in the plots treated with deltamethrin 2.8 EC @ 
$1 \mathrm{ml} / \mathrm{l}$ was at par with chlorantraniliprole 18.5 SC @ 0.3gm/l (11.47\%). These treatments were found to be superior in reducing shoot fly damage over rest of the treatment.

The next best treatment was flubendiamide 20 WG @ 0.2gm/l (13.41\%) and quinalphos 25 EC@2ml/1 (14.10\%) and was at par with each other. However, these were followed by azadirachtin 10,000 PPM @ 3ml/1 (15.46\%), buprofezin 25 SC @ 1.25ml/1 (15.89\%).

All these treatments were significantly superior over untreated control. Maximum dead hearts were recorded in untreated control $(17.01 \%)$.

\section{References}

F. A. O., 2011. FAOSTAT. http: // faostat.fao.org
Panchbhavi, K.S., and Kotikal, Y.K. 1992. Effect of seed soaking in insecticides solution on germination and on the incidence of shoot fly. Curr. Res., 21: 202-203.

Patil, B. V., Bheemanna, M., Somasekhar and Hiremath, S. C. 1992. Effect of seed soaking in insecticides on sorghum shoot fly, Atherigona soccata Rondani. Indian J. Ent., 54: 424-427.

Pawar, D.B., Bhoge R.S., and Gadakh S.R. 2015. Effect of sowing dates, varieties and insecticides on shoot fly incidence and grain yield of rabi sorghum. A Quarterly Journal of Life Sciences, 12 (2A): 426-429.

Shivpuje, P.R., and Thombare, P.A. 1983. Efficacy of different insecticide against sorghum for control of sorghum shoot fly. J. Maharashtra Agric Univ., 8: 83.

\section{How to cite this article:}

Patil, S.P. and Bagde, A.S. 2017. Effect of New Molecules of Insecticides on Shoot Fly (Atherigona soccata) (Rondani) Incidence and Grain Yield of Sorghum. Int.J.Curr.Microbiol.App.Sci. 6(9): 2751-2754. doi: https://doi.org/10.20546/ijcmas.2017.609.339 